\title{
Response to cobalt toxicity in lichen Pseudevernia furfuracea; uptake, photosynthetic quantum yield, membrane integrity and deoxyribonucleic acid fragmentation
}

\author{
Pseudevernia furfuracea' da kobalt toksisitesine yanıt; alım, fotosentetik kuantum verimi, \\ membran bütünlüğü ve deoksiribonükleik asit fragmantasyonu
}

\author{
Gürkan Yiğittürk, ${ }^{1}$ Dilek Ünal-Özakça, ${ }^{2}$ Türker Çavuşoğlu ${ }^{1,3}$ Kubilay Doğan Kılıç, ${ }^{1}$ \\ Yiğit Uyanıkgil, ${ }^{1,3}$ Atakan Sukatar ${ }^{4}$ \\ ${ }^{1}$ Department of Histology and Embryology, Medical Faculty of Ege University, İzmir, Turkey \\ ${ }^{2}$ Department of Molecular Biology and Genetics, Bilecik Seyh Edebali University, Faculty of Science and Art, Bilecik, Turkey \\ ${ }^{3}$ Ege University, Cord blood, Cell-Tissue Research and Application Center, İzmir, Turkey \\ ${ }^{4}$ Department of Biology, Ege University, Faculty of Applied Science, İzmir, Turkey
}

\begin{abstract}
Objectives: This study aims to examine the toxic potential of Cobalt (Co) on photosystem II photosynthetic quantum yield, membrane integrity, and deoxyribonucleic acid (DNA) fragmentation formation.

Materials and methods: Oligonucleosomal DNA fragmentation was detected by terminal deoxynucleotidyl transferase-dUTP nick end labeling (TUNEL) assay. Lipid peroxidation was determined with malondialdehyde analyzing.

Results: The Fv/Fm ratio decreased in Pseudevernia furfuracea following exposure to various concentrations of $\mathrm{Co}\left(\mathrm{NO}_{3}\right)_{2}(5,15$ and $30 \mathrm{mM})$ for one, three and 24 hours. $\mathrm{Co}^{2+}$-treatment caused the accumulation of $\mathrm{Co}$ in lichen, induced severe oxidative stress by the generation of hydrogen peroxide, impaired the membrane integrity, and induced lipid peroxidation as measured by malondialdehyde. Samples treated with $15 \mathrm{mM}$ and $30 \mathrm{mM}$ of Co $\left(\mathrm{NO}_{3}\right)_{2}$ had higher percentage of cell death than $5 \mathrm{mM}$-treated group.

Conclusion: To our knowledge, this is the first study detecting a high rate of DNA fragmentation in situ in phycobiont layer of Pseudevernia furfuracea; while it reveals that mycobiont layer has a lower rate of TUNEL-positive cells. It has been concluded that Co exposure results in impaired photosynthesis accompanied by oxidative stress and DNA fragmentation in Pseudevernia furfuracea; all these effects were concentration-dependent.

Keywords: Cobalt; deoxyribonucleic acid fragmentation; lichen; oxidative stress; Pseudevernia furfuracea; TUNEL.
\end{abstract}

öz

Amaç: Bu çalışmada fotosistem II fotosentetik kuantum verimi, membran bütünlüğü ve deoksiribonükleik asit (DNA) fragmantasyonu formasyonu üzerinde kobaltın (Co) toksik potansiyeli incelendi.

Gereç ve yöntemler: Oligonükleozomal DNA fragmantasyonu terminal deoksinükleotidil transferaz dUTP çentik uç işaretleme (TUNEL) testi ile tespit edildi. Lipid peroksidasyonu malondialdehit analizi ile belirlendi.

Bulgular: Bir, üç ve 24 saat boyunca farklı Co konsantrasyonlarına $\left(\mathrm{NO}_{3}\right)_{2}(5,15$ ve $30 \mathrm{mM})$ maruziyetten sonra Pseudevernia furfuracea'da Fv/Fm oranı azaldı. Co ${ }^{2+}$-tedavisi likende Co birikimine yol açtı, hidrojen peroksit üretimi ciddi oksidatif stres başlattı, membran bütünlüğüne zarar verdi ve malondialdehit ile ölçüldüğü üzere lipid peroksidasyonu oluşturdu. On beş $\mathrm{mM}$ ve $30 \mathrm{mM} \mathrm{Co}\left(\mathrm{NO}_{3}\right)_{2}$ ile tedavi edilen örneklerin hücre ölümü yüzdesi $5 \mathrm{mM}$ ile tedavi edilen gruptan daha yüksek idi.

Sonuç: Bildiğimiz kadarıyla, bu çalışma Pseudevernia furfuracea'nın fikobiont katmanında in situ yüksek oranda DNA fragmantasyonu tespit ederken mikobiont katmanda daha düşük oranda TUNEL pozitif hücre olduğunu gösteren ilk çalışmadır. Kobalt maruziyetinin Pseudevernia furfuracea'da oksidatif stres ve DNA fragmantasyonunun eşlik ettiği bozulmuş fotosenteze yol açtığı sonucuna varıldı; tüm bu etkiler konsantrasyona bağımlı idi.

Anahtar sözcükler: Kobalt; deoksiribonükleik asit fragmantasyonu; liken; oksidatif stres; Pseudevernia furfuracea; TUNEL. 
Cobalt (Co) is an element that occurs naturally in many different chemical forms in the environment. It is an essential element for the synthesis of vitamin $\mathrm{B}$, which is required for human and animal nutrition. ${ }^{[1]}$ However, high concentrations of Co are inhibitory for growth, chlorophyll synthesis and induce changes in photosynthetic activity. ${ }^{[2-4]}$ Toxicity symptoms due to excess Co are chlorosis, necrosis, and root tip damage in higher plants.

Lichens are potentially useful in the monitoring of heavy metal pollution. Their reaction to pollution is a consequence of the fact that, comparing to plant species, they do not have an outer covering tissue which facilitates direct penetration of gases, dusts and solutions inside the thalli. Some lichen species can accumulate large quantities of metals. ${ }^{[5]}$ However, high concentrations of heavy metals may cause damage to the lichen thalli. Cobalt bioaccumulation and biosorption has been recently studied; however, there are no data available on the effect of Co on the cellular processes in lichens. This study aimed to investigate the potential toxic effect of Co on photosynthesis, oxidative stress, and DNA fragmentation. ${ }^{[6,7]}$

\section{MATERIALS AND METHODS}

Pseudevernia furfuracea (L.) Zopf samples were collected from bark of Pinus in Karagöl, Izmir-

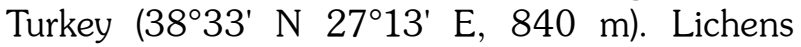
transferred to the laboratory were rinsed three times (10 s each) to minimize dust contamination and divided into groups. Experiments were conducted within 3-4 days of collection. The test solutions were prepared just before the experiments. Samples were incubated for $1 \mathrm{~h}$ in solutions of $\mathrm{Co}\left(\mathrm{NO}_{3}\right)_{2}$ dissolved in bidistilled water (5 mM, $15 \mathrm{mM}$ and $30 \mathrm{mM}$ ); control samples were soaked in distilled water. After incubation, lichen thalli were kept for $24 \mathrm{~h}$ under laboratory conditions.

For the determination of Co content, the threestage microwave-assisted digestion procedure was applied using a microwave oven (Berghof, speedwave) under a pressure of $8 \mathrm{~atm}$. In the first stage, lichen sample $(0.5 \mathrm{~g})$ was washed three times with distilled water and decomposed with $5 \mathrm{~mL}$ of $\mathrm{HNO}_{3}$ for $10 \mathrm{~min}$. The sample was cooled, vented to remove $\mathrm{NO}_{2}$ and $\mathrm{CO}_{2}$ and $1 \mathrm{~mL}$ of $\mathrm{H}_{2} \mathrm{O}_{2}$ was added. The vessel was capped and subjected to microwave attack for $10 \mathrm{~min}$ (second stage). In the third stage, $1 \mathrm{~mL}$ of hydrogen fluoride was added and the sample was processed for $10 \mathrm{~min}$. After cooling, the sample was transferred to a polytetrafluoroethylene (PTFE) evaporating dish and evaporated to dryness. The residue was then processed as described above. Co concentration was measured by inductively coupled plasma optical emission spectrometer (ICP-OES). Each treatment was comprised of three replicates.

For the detection of photosynthetic capacity of lichen, chlorophyll a fluorescence of samples was measured with a plant efficiency analyzer (Handy PEA, Hansatech). Before measurement of chlorophyll fluorescence, the thalli were darkadapted for $15 \mathrm{~min}$. The Fv/Fm parameter was calculated by the instrument from fluorescence induction curves of $5 \mathrm{~s}$ duration recorded at an irradiance of $1800 \mu \mathrm{mol} \mathrm{m}-2 \mathrm{~s}-1$ from light emitting diodes. The Fv/Fm parameter defines the maximum quantum yield efficiency of photosystem II (PSII) and was used as a stress indicator. Time-dependency of the effect of Co on PSII was also tested in thalli samples exposed to $5 \mathrm{mM}, 15 \mathrm{mM}$ and $30 \mathrm{mM}$ $\mathrm{Co}\left(\mathrm{NO}_{3}\right)_{2}$ for 1,3 and $24 \mathrm{~h}$.

Electrical conductivity (EC) as an index of cellular membrane integrity was measured. Batches of lichen thalli were divided into subsamples of $1 \mathrm{~g}$ and immersed in $100 \mathrm{~mL}$ of double-distilled water for $60 \mathrm{~min}$. Electrical conductivity of the water was measured by an EC meter (WTW Cond 340i) and is used as a measure of electrolyte leakage to the incubation solution.

Formation of malondialdehyde (MDA) was evaluated as an indicator of lipid peroxidation. Determination of MDA was performed by the thiobarbituric acid reactive substances method. ${ }^{[8]}$ The absorbance differences between 532 and $600 \mathrm{~nm}$ was used to calculate MDA formation as a by-product of lipid peroxidation. Each treatment was comprised of three replicates.

Hydrogen peroxide $\left(\mathrm{H}_{2} \mathrm{O}_{2}\right)$ levels were determined according to Sergiev et al. ${ }^{[9]}$ Leaf tissues of $0.5 \mathrm{~g}$ were homogenized in ice bath

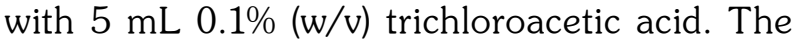
homogenate was centrifuged at $12,000 \mathrm{~g}$ for $15 \mathrm{~min}$ and $0.5 \mathrm{~mL}$ of supernatant was added to 
$0.5 \mathrm{~mL}$ of $10 \mathrm{mM}$ potassium phosphate buffer ( $\mathrm{pH} \mathrm{7.0)}$ and $1 \mathrm{~mL} 1 \mathrm{M}$ potassium iodide. The absorbance of supernatant was read at $390 \mathrm{~nm}$. The content of $\mathrm{H}_{2} \mathrm{O}_{2}$ was calculated based on a standard curve.

For DNA fragmentation assay, the thallus was cut into the small pieces and then fixed with FAA solution (50\% ethanol, 5\% glacial acetic acid, $3.7 \%$ formaldehyde, freshly prepared) and incubated in this solution overnight. Fixed samples were dehydrated through an ethanol series $(50 \%, 70 \%, 80 \%, 95 \%, 100 \%$ for $15 \mathrm{~min}$ each concentration), immersed in ethanol-xylene (1:1) for $10 \mathrm{~min}$ and then in $100 \%$ xylene for $10 \mathrm{~min}$. The samples were embedded in paraffin, and cut to $5 \mu \mathrm{m}$ sections in Leica RM 2145 microtome (Leica Microsystems, RM2145, Glattbrugg, Switzerland).

Immunohistochemical expression was analyzed in the lichen thallus tissue using peroxidase as described in details below. Paraffin sections were immersed in xylene overnight and immunohistochemical terminal deoxynucleotidyl transferase dUTP nick end labeling (TUNEL) staining was performed as follows: sections were incubated for $20 \mathrm{~min}$ in methanol containing $1 \% \mathrm{H}_{2} \mathrm{O}_{2}$ to reduce endogenous peroxidase activity and then exposed to microwave in sodium citrate solution for five minute 90 watt - 15 minute 360 watt. After washing in $0.2 \mathrm{M}$ Tris- $\mathrm{HCl}$ including $0.5 \%$ Triton $\mathrm{X}$, the sections were exposed to the TUNEL (Promega TUNEL Systems Cat. \# G7130-G7360). Finally, sections were reacted with $0.05 \%$ diaminobenzidine (Zymed Histostain Plus Ref/Cat No: 859643 San Francisco California, USA) and $\mathrm{H}_{2} \mathrm{O}_{2}$ (0.01\%). Immunoreaction was assessed by light microscopy (Olympus BX-51 light microscope, Olympus C-5050 digital camera; Olympus Co., Tokyo, Japan) at a magnification of X100. TUNEL (+) cells were counted in the lichen thallus using image software (Image-Pro Express 4.5, Media-Cybernetics Inc., Rockville, MD, USA). Cell density (cells $\mu \mathrm{m}^{2}$ ) was calculated for lichen and the average TUNEL (+) cell density was obtained in each group.

\section{Statistical analysis}

Data were expressed as the mean \pm standard error of the mean (SEM). One-way analysis of variance (ANOVA) was performed for the statistical analysis of $\mathrm{Fv} / \mathrm{Fm}$ ratios and nonparametric Kruskal Wallis test for independent samples was performed for the rest of the analysis. $\mathrm{P}<0.05$ was accepted significant; when a $P$ value below 0.05 was determined, Bonferroni test or Mann Whitney $\mathrm{U}$ test was carried out in post hoc analysis for the comparison of groups where appropriate SPSS for Windows version 11.0 version software (SPSS Inc., Chicago, IL, USA).

\section{RESULTS}

ICP-OES data showed that the concentration of $\mathrm{Co}$ in the untreated thallus of $P$. furfuracea soaked in bidistilled water was $3.49 \pm 0.04 \mu \mathrm{g} / \mathrm{g}$ dry weight. On the other hand, treatment of thalli with $5 \mathrm{mM}, 15 \mathrm{mM}$, and $30 \mathrm{mM}$ $\mathrm{Co}\left(\mathrm{NO}_{3}\right)_{2}$ for $1 \mathrm{~h}$ resulted in a significant dosedependent increase in the Co content of thallus (64.12 $\pm 11.37,108.63 \pm 0.58$ and $216.17 \pm 3.62$ $\mathrm{\mu g} / \mathrm{g}$ dry weight, respectively; $\mathrm{p}<0.05$ when compared to control group and when compared to exposure groups with each other).

For the estimation of the effect of Co on photosynthesis capacity of the thallus, photoinhibition was measured with permanent reduction in maximal PSII efficiency (Fv/Fm). There was a gradual, time- and dose-dependent decrease in the $\mathrm{Fv} / \mathrm{Fm}$ values in $\mathrm{Co}^{2+}$-exposure

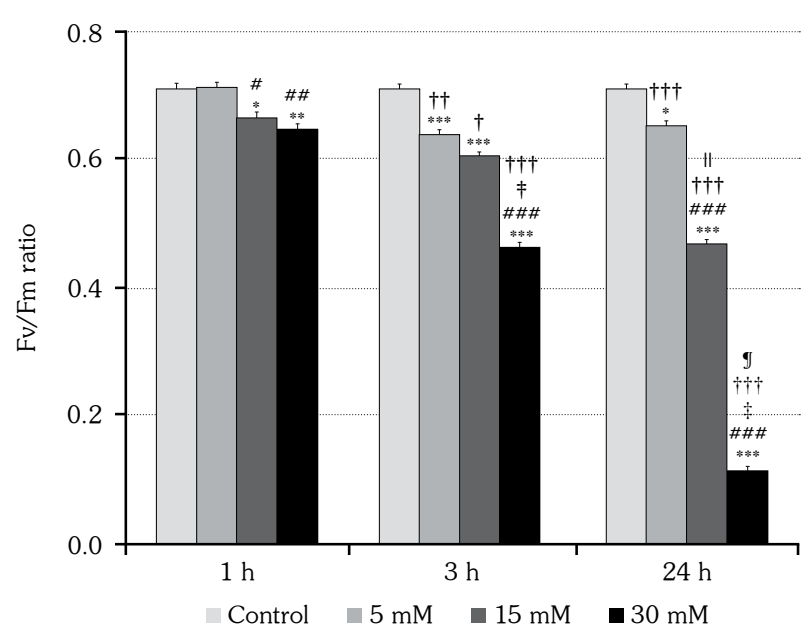

Figure 1. Fv/Fm ratio of $P$. furfuracea thalli immersed in bidistilled water or in different concentrations of $\mathrm{Co}$ $\left(\mathrm{NO}_{3}\right)_{2}$. Data are presented as mean $\pm \mathrm{SEM}$ of eight individual experiments. ${ }^{*} \mathrm{P}<0.05,{ }^{* *} \mathrm{P}<0.01$ and ${ }^{* * * *} \mathrm{P}<0.001$, when compared to control; \# $\mathrm{P}<0.05$, \#\# $\mathrm{P}<0.01$ and \#\#\# $\mathrm{P}<0.001$, when compared to $5 \mathrm{mM}$ group; $\ddagger \mathrm{P}<0.001$, when compared to $15 \mathrm{mM}$ group; $\dagger \mathrm{P}<0.05$, $\dagger \mathrm{P}<0.01$ and t† $\mathrm{P}<0.001$, when compared to corresponding 1 hour exposure data; $\S \mathrm{P}<0.05$, I| $\mathrm{P}<0.01$ and If $\mathrm{P}<0.001$, when compared to corresponding 3 hours exposure data. 
Table 1. Electrical conductivity and malondialdehyde and hydrogen peroxide content of $P$. furfuracea thalli incubated in bidistilled water (control) or in different concentrations of $\mathrm{Co}\left(\mathrm{NO}_{3}\right)_{2}$ for 24 hours

\begin{tabular}{|c|c|c|c|}
\hline & Electrical conductivity $\left(\mu \mathrm{S} \mathrm{cm}^{-1}\right)$ & Malondialdehyde $(\mu \mathrm{M})$ & $\mathrm{H}_{2} \mathrm{O}_{2}(\mu \mathrm{M})$ \\
\hline & Mean \pm SEM & Mean \pm SEM & Mean \pm SEM \\
\hline Control & $2.53 \pm 0.26$ & $1.72 \pm 0.54$ & $1.66 \pm 0.12$ \\
\hline 5 mM Co(NO 3$)_{2}$ & $3.33 \pm 0.60$ & $2.43 \pm 0.01$ & $6.23 \pm 0.10^{*}$ \\
\hline $15 \mathrm{mM} \mathrm{Co}\left(\mathrm{NO}_{3}\right)_{2}$ & $9.40 \pm 0.56^{*}, \neq$ & $7.51 \pm 0.67^{*}, \neq$ & $11.79 \pm 0.20^{*}, \neq$ \\
\hline $30 \mathrm{mM} \mathrm{Co}\left(\mathrm{NO}_{3}\right)_{2}$ & $18.77 \pm 0.59^{*}, \neq, \Phi$ & $14.38 \pm 0.26^{*}, \neq, \boldsymbol{J}$ & $51.53 \pm 2.07^{*}, \neq, \mathbb{I}$ \\
\hline
\end{tabular}

SEM: Standard error of the mean; $\mathrm{H}_{2} \mathrm{O}_{2}$ : Hydrogen peroxide; ${ }^{*} \mathrm{P}<0.05$, when compared to control; $\neq \mathrm{P}<0.05$, when compared to $5 \mathrm{mM}$ group; I $\mathrm{P}<0.05$, when compared to $15 \mathrm{mM}$ group.

groups, indicating a significant photodestructive effect on PSII (Figure 1).

Cellular membrane integrity was assessed by the measurement of $\mathrm{EC}$ in the incubation solution. It was noticed that $\mathrm{Co}^{2+}$ exposure of thalli for $24 \mathrm{~h}$ increased the EC at 15 and $30 \mathrm{mM}$ concentrations significantly when compared to the control group $(\mathrm{P}<0.05$, Table 1) and this effect was concentration-dependent; indicating a marked impairment in the membranal integrity of the thalli.
Table 1 shows the MDA and $\mathrm{H}_{2} \mathrm{O}_{2}$ content of thalli after exposure to $\mathrm{Co}^{2+}$ for $24 \mathrm{~h}$. $\mathrm{Co}^{2+}$ exposure significantly increased the MDA content of thalli at $15 \mathrm{mM}$ and $30 \mathrm{mM}$, but not at $5 \mathrm{mM}$, concentrations $(p<0.05)$, while it increased $\mathrm{H}_{2} \mathrm{O}_{2}$ content at all concentrations. The increase in MDA level, as an index of lipid peroxidation, and $\mathrm{H}_{2} \mathrm{O}_{2}$ level was in a concentration-dependent manner.

Tissue sections of thallus from $P$. furfuracea were examined for TUNEL-positive nuclei, which
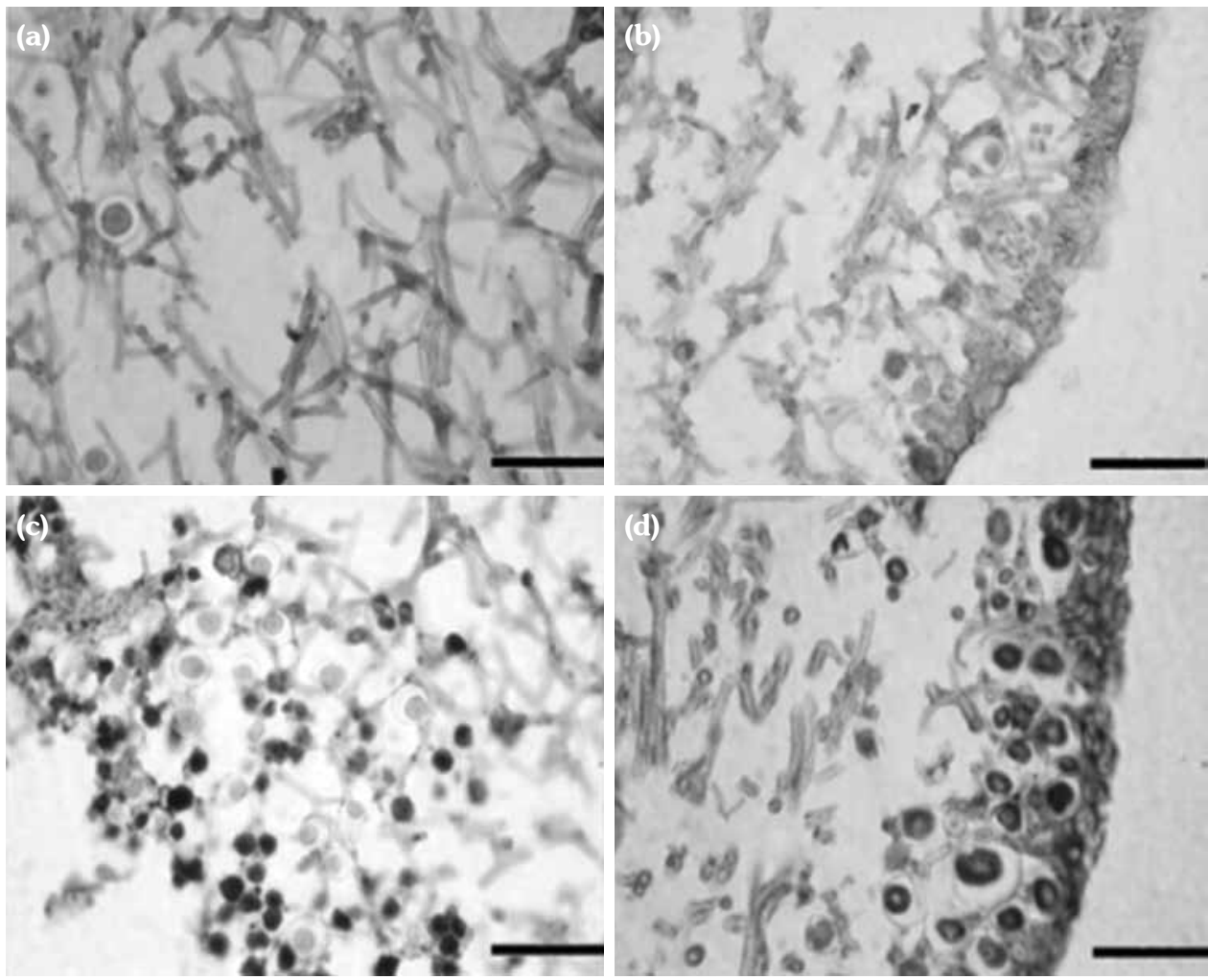

Figure 2. TUNEL staining of the sections of lichen incubated in (a) bidistilled water (control group), (b) $5 \mathrm{mM} \mathrm{Co}\left(\mathrm{NO}_{3}\right)_{2}$, (c) $15 \mathrm{mM} \mathrm{Co}\left(\mathrm{NO}_{3}\right)_{2}$ or (d) $30 \mathrm{mM} \mathrm{Co}\left(\mathrm{NO}_{3}\right)_{2}$. Original magnification x 40. Scale bar $=125 \mu \mathrm{m}$. Dark nuclei are TUNEL (+) cells. 


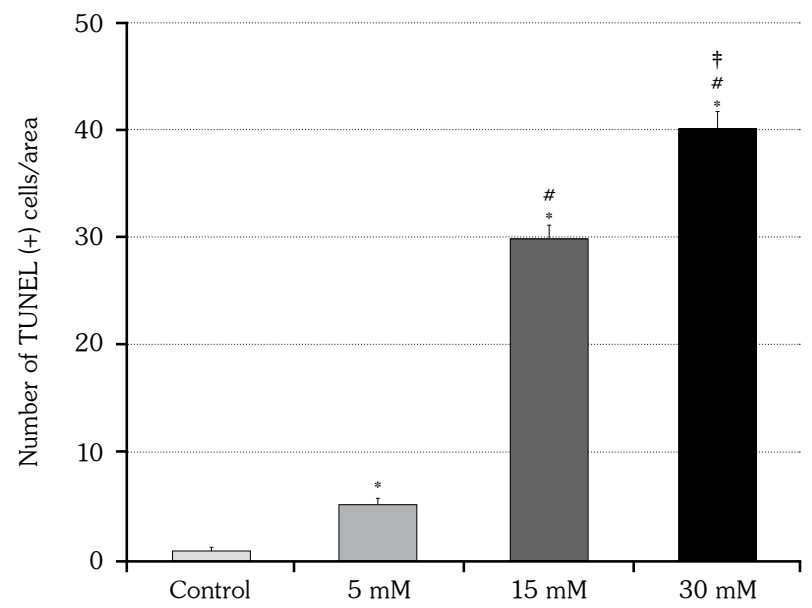

Figure 3. Number of TUNEL (+) cells in lichen thallus sections. Data are presented as mean \pm SEM of three individual experiments. " $\mathrm{P}<0.001$, when compared to control; \# $\mathrm{P}<0.001$, when compared to $5 \mathrm{mM}$ group; $¥ \mathrm{P}<0.001$, when compared to $15 \mathrm{mM}$ group.

were noticed as dark brown spots (Figure 2). In mycobiont layer, TUNEL-positive nuclei were less frequently scattered in $\mathrm{Co}^{2+}$ exposure groups comparing to the intensity of TUNELpositive nuclei in the phycobiont layer of thallus (Figure 2). In total, exposure of thalli to $\mathrm{Co}^{2+}$ resulted in a significant increase in the number of TUNEL-positive cells in a concentrationdependent manner ( $p<0.001$, Figure 3). When the distribution of TUNEL-positive cells among the two layers of lichen was statistically examined; it was noticed that the percentage of TUNELpositive cells in the photobiont was higher than the mycobiont both in the control group $(p<0.05)$ and in the $\mathrm{Co}^{2+}$ exposure groups $(\mathrm{p}<0.01$ in 5 and $30 \mathrm{mM}$ groups and $\mathrm{p}<0.00115 \mathrm{mM}$ group) (Table 2).

Table 2. The percentage of TUNEL positive nuclei of mycobiont and photobiont layers of $P$. furfuracea thalli immersed in bidistilled water (control) or in different concentrations of $\mathrm{Co}\left(\mathrm{NO}_{3}\right)_{2}$ for 24 hours

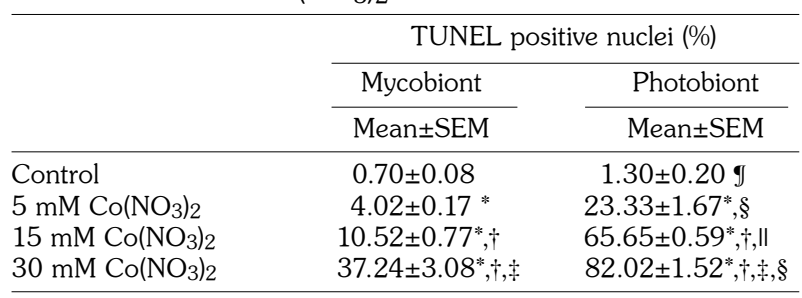

SEM: Standard error of the mean; $\mathrm{P}<0.05$, when compared to control; $\dagger \mathrm{P}<0.05$, when compared to $5 \mathrm{mM}$ group; $\doteqdot \mathrm{P}<0.05$, when compared to 15 mM group; If $\mathrm{P}<0.05$, \& $\mathrm{P}<0.01$, I| $\mathrm{P}<0.001$, when compared to mycobiont layer.

\section{DISCUSSION}

Lichens do not shed plant parts as readily as vascular plants. ${ }^{[5,10]}$ The lack of a waxy cuticle and stomata allows them to adsorb many contaminants through the whole lichen surface. ${ }^{[5]}$ Lichens are capable of accumulating various elements to concentrations that vastly exceed their physiological requirements and therefore, deposition patterns are distinguishable from normal element loadings. ${ }^{[5]}$ Data obtained in lichen samples incubated in $\mathrm{Co}\left(\mathrm{NO}_{3}\right)_{2}$ in our study show that Co content rapidly increases in $P$. furfuracea with the increasing Co concentration in the incubation solution. Exposure to $\mathrm{Co}\left(\mathrm{NO}_{3}\right)_{2}$ produced an accumulation of Co in $P$. furfuracea thallus at a considerably high level (i.e. $216.73 \mu \mathrm{g} / \mathrm{g}$ dry weight at exposure to $30 \mathrm{mM} \mathrm{Co}^{2+}$ ) that had a capacity to inhibit photosynthesis significantly.

Maximal PSII efficiency is frequently used to monitor stress in photosynthetic organisms. Under non-stressed conditions, lichens typically possess a $\mathrm{Fv} / \mathrm{Fm}$ ratio in the range of $0.45-0.65$. ${ }^{[1]}$ The decrease of Fv/Fm ratio in the lichen $P$. furfuracea is in accordance with studies on the impact of $\mathrm{Co}^{2+}$ stress on algae. ${ }^{[12]}$ Plekhanov and Chemeris ${ }^{[12]}$ showed that the Fv/Fm ratio in Chlorella pyrenoidosa treated with $0.1,1$, and $10 \mathrm{mM} \mathrm{Co}^{2+}$, rapidly decreased to $0.45,0.25$, and 0.15 , respectively. In the present study, 24-hour exposure to $\mathrm{Co}^{2+}$ resulted in $\mathrm{Fv} / \mathrm{Fm}$ values of 0.47 and 0.1 at $15 \mathrm{mM}$ and $30 \mathrm{mM}$ concentrations; suggesting that particularly at $30 \mathrm{mM}, \mathrm{Co}^{2+}$ decreases the photosynthesis capacity of lichen below the non-stressed levels and induces significant photo-destructive effects on PSII, respectively.

Oxidative stress caused lipid peroxidation and thereby destruction of cell membranes. [13] Although the toxicity of $\mathrm{Co}$ is quite low compared to many other metals in soil, the toxic action of Co was found to be altering membrane permeability. ${ }^{[14,15]}$ Turton et al. ${ }^{[16]}$ suggested that the presence of MDA in biological systems can be related to the peroxidation of unsaturated fatty acids constituting cellular membranes. The consequences of the changes in lipid and protein structure are the loss of membrane integrity and selective permeability. Thus, the increase in MDA levels suggests that higher concentration 
of $\mathrm{Co}^{2+}$ has a damaging effect on the cellular membranes of $P$. furfuracea. In present study, the concentration-dependent increase in MDA levels shows a positive correlation with the EC values in such a manner that the higher MDA levels in lichen, the higher EC in the incubation solution. Electrical conductivity is considered to indicate injury to cell membranes and has been previously used for the assessment of electrolyte leakage in lichen. ${ }^{[17,18]}$ Although $5 \mathrm{mM} \mathrm{Co}^{2+}$ exposure did not significantly change EC in thalli, marked higher EC values were observed in thalli treated with $5 \mathrm{mM}$ and $30 \mathrm{mM}$ concentration of $\mathrm{Co}^{2+}$; indicating the leakage of electrolytes through the damaged membranes of the lichen.

$\mathrm{H}_{2} \mathrm{O}_{2}$ is toxic for most animal cells at levels of about $10-10^{2} \mu \mathrm{M} \cdot{ }^{[19]}$ Experiments with plant material have demonstrated that plant tissues can tolerate high concentrations of $\mathrm{H}_{2} \mathrm{O}_{2}$ in the range of $10^{2}-2 \times 10^{5} \mu \mathrm{M} \cdot{ }^{[20]} \mathrm{H}_{2} \mathrm{O}_{2}$ increase has been reported in Arabidopsis thaliana and tomato plants after treatment with copper, cadmium and mercury. ${ }^{[21-23]}$ Photosynthetic efficiency data in our study has shown that thallus of $P$. furfuracea can tolerate concentrations of $\mathrm{H}_{2} \mathrm{O}_{2}$ at an approximate range of $6-52 \mu \mathrm{M}$ (see Table 1 ). de Pinto et al. ${ }^{[24]}$ showed that only simultaneous increase of $\mathrm{H}_{2} \mathrm{O}_{2}$ in tobacco cells induced cell death that had typical cytological and biochemical features of DNA fragmentation. Similarly, our results have shown that increasing production of $\mathrm{H}_{2} \mathrm{O}_{2}$ induces a marked increase in the density of TUNEL-positive cells in P. furfuracea thalli. TUNEL-positive nuclei were examined less frequently in mycobiont layer compared to the photobiont layer, suggesting the photobiont layer is more sensitive to Co-induced toxicity than mycobiont layer.

In conclusion, our data have clearly indicated that exposure to $\mathrm{Co}^{2+}$ increases the Co content of the lichen and consequently results in decreased photosynthetic quantum yield. This functional Co toxicity is accompanied by lipid peroxidation and consecutive damage to cellular membrane integrity and oxidative stress-induced formation of DNA fragmentation especially in the photobiont layer. Results of the present study, however, do not clearly identify that the feature of DNA fragmentation is directly related to apoptotic-like formation or necrosis. Further focused research is required to investigate the characteristics of the formation of DNA fragmentation related to necrosis or apoptosis in lichen under heavy metal stress conditions.

\section{Acknowledgments}

The authors of the current study would like to thank Dr. Şenol Sert for helping the ICP-OES analysis.

\section{Declaration of conflicting interests}

The authors declared no conflicts of interest with respect to the authorship and/or publication of this article.

\section{Funding}

The authors received no financial support for the research and/or authorship of this article.

\section{REFERENCES}

1. Munda LM, Hudnik V. The effect of Zn, Mn and Co accumulation on growth and chemical composition of Fucus vesiculosus under different temperature and salnity conditions. Mar Ecol 1988;9:213-5.

2. Csatorday K, Gombos Z, Szalontai B. Mn and Co toxicity in chlorophyll biosynthesis. Proc Natl Acad Sci U S A 1984;81:476-8.

3. El-Naggar AH, Osman MEH, Dyab MA, El-Mohsenawy EA. Co and lead toxicities on Calothrix fusca and Nostoc muscorum. Egypt J Bot 1999;421-41.

4. Tiwari S, McHanty P. Cobalt induced changes in photosystem activity in Synechocystis PCC 6803: Alterations in energy distribution and stoichiometry. Photosynth Res 1996;50:243-56.

5. Nash III TH. Lichen Biology. New York: Cambridge University Press; 1996. p. 147-50.

6. Pipíska M, Horník M, Vrtoch L, Augustín J, Lesny J. Biosorption of $\mathrm{Co} 2+$ ions by lichen Hypogymnia physodes from aqueous solutions. Biologia 2007;62:276-82.

7. Freitas MC, Pacheco AMG. Bioaccumulation of $\mathrm{Co}$ in Parmelia sulcata. J Atmos Chem 2004;49:67-82.

8. Heath RL, Packer L. Photoperoxidation in isolated chloroplasts. I. Kinetics and stoichiometry of fatty acid peroxidation. Arch Biochem Biophys 1968;125:189-98.

9. Sergiev I, Alexieva V, Karanov E. Effect of spermine, atrazine and combination between them on some endogenous protective systems and stress markers in plants. Compt Rend Acad Bulg Sci 1997;51:121-4.

10. Loppi S, Pirintsos SA, de Dominicis V. Soil contribution to the elemental composition of epiphytic lichens (Tuscany, central Italy). Environ Monit Assess 1999;58:121-31.

11. Kappen L, Schroeter B, Green TGA, Seppelt RD. Chlorophyll a fluorescence and $\mathrm{CO} 2$ exchange of Umblicaria aprina under extreme light stress in the cold. Oecologia 1998;113:325-31. 
12. Plekhanov SE, Chemeris IuK. Early toxic effect of zinc, cobalt, and cadmium on photosynthetic activity of green alga Chlorella pyrenoidosa Chick S-39. Izv Akad Nauk Ser Biol 2003;5:610-6. [Abstract]

13. Vangronsveld J, Clijsters H. Toxic effects of metals. In: Farago ME, editor. Plants and the Chemical Elements. Biochemistry, Uptake, Tolerance and Toxicity. Weinheim: VCH Verlagsgesellschaft Publishers; 1994. p. 149-77.

14. Rachlin JW, Grosso A. The growth response of the green alga Chlorella vulgaris to combined divalent cation exposure. Arch Environ Contam Toxicol 1993;24:16-20.

15. Osman ME, El-Naggar AH, El-Sheekh MM, El-Mazally EE. Differential effects of $\mathrm{Co}(2+)$ and $\mathrm{Ni}(2+)$ on protein metabolism in Scenedesmus obliquus and Nitzschia perminuta. Environ Toxicol Pharmacol 2004;16:169-78.

16. Turton HE, Dawes IW, Grant CM. Saccharomyces cerevisiae exhibits a yAP-1-mediated adaptive response to malondialdehyde. J Bacteriol 1997;179:1096-101.

17. Garty J, Cohen Y, Kloog N, Karnieli A. Effects of air pollution on cell membrane integrity, spectral reflectance and metal and sulfur concentrations in Lichens. Environ Toxicol Chem 1997;16:1396-402.

18. Backor M, Fahselt D, Davidson RD, Wu CT. Effects of copper on wild and tolerant strains of the lichen photobiont Trebouxia erici (Chlorophyta) and possible tolerance mechanisms. Arch Environ Contam Toxicol 2003;45:159-67.

19. Halliwell B, Gutteridge JMC. The chemistry of free radicals and related reactive species. In: Free radicals in biology and medicine. Oxford: Oxford University Press; 1999. p. 36-104.

20. Slesak I, Libik M, Karpinska B, Karpinski S, Miszalski $\mathrm{Z}$. The role of hydrogen peroxide in regulation of plant metabolism and cellular signalling in response to environmental stresses. Acta Biochim Pol 2007;54:39-50.

21. Romero-Puertas MC, Rodriquez-Serrano M, Corpas FJ, Go'mez M, Del Rio LA, Sandalio LM. Cadmiuminduced subcellular accumulation of $\mathrm{O} 2-$ and $\mathrm{H} 2 \mathrm{O} 2$ in pea leaves. Plant Cell Environ 2004;27:1122-34.

22. Maksymiec W, Krupa Z. The effects of short-term exposition to $\mathrm{Cd}$, excess $\mathrm{Cu}$ ions and jasmonate on oxidative stress appearing in Arabidopsis thaliana. Environ Exp Bot 2006;57:187-94.

23. Cho U, Park J. Mercury-induced oxidative stress in tomato seedlings. Plant Sci 2000;156:1-9.

24. de Pinto MC, Tommasi F, De Gara L. Changes in the antioxidant systems as part of the signaling pathway responsible for the programmed cell death activated by nitric oxide and reactive oxygen species in tobacco Bright-Yellow 2 cells. Plant Physiol 2002;130:698-708. 